\title{
Læringscyklusser. Tekstforståelse og informationshåndtering, forbundet i én læreproces
}

\author{
Volkmar Engerer, lektor, Det Informationsvidenskabelige Akademi, Københavns \\ Universitet.
}

\section{Reviewet artikel}

Denne artikel er et forsøg på at knytte den traditionelle tekstbaserede humanistiske læring på universitetet til informationshåndterende aktiviteter som fx litteratursøgning. Der tages udgangspunkt i en kognitiv-konstruktivistisk læringsforståelse under decideret henvisning til dens individuelkognitive og gruppemæssig-sociale elementer. Både selve tekstforståelsen og dynamikken mellem forståelsesbaserede og teksthåndterende aktiviteter konciperes cyklisk. Tekstforståelse som lxringsaktivitet består i cykliske skift mellem en individuel, kognitiv bearbejdelse af stoffet og en kommunikativ afprovning af den opnåede viden i den lærende gruppe. Overgangen mellem forståelsesorienteret læring og tekstsøgning er ligesom cyklisk struktureret, da informationssøgningsaktiviteter både tager afsæt fra og peger hen imod en fordybet tekstforståelse, idet al meningsfuld håndtering af information, udvidelse eller vinkling baserer sig på en forudgående forståelse af udgangstekster. Samtidig leder alle informationssøgningsaktiviteter hen til en ny forståelse, hvor udvidelsen/vinklingen intellektuelt forarbejdes $i$ en ny runde af forstående læsning. Hovedsigtet med denne artikel er at pege på dynamikken $i$ en iterativ universitetspæadagogisk læringsmodel, hvor tekstforståelse og -håndtering skifter med hinanden i en, for den lærende, meningsfyldt sekvens. Dette har bl.a. den pædagogiske konsekvens, at man allerede i undervisningen bør tilstræbe ikke at begrænse læring til tekstforstående aktiviteter alene, men at placere dem $i$ undervisningen på en didaktisk vis i en frugtbar læringsmæssig sammenhæng med informationshåndterende aktiviteter.

\section{Introduktion: 1æring og informationshåndtering}

Hvad er læring i rammerne af højere uddannelsesinstitutioner (her universiteter) og hvordan hænger denne læring sammen med informationshåndterende læringsaktiviteter som $\mathrm{fx}$ at finde ny litteratur om et emne? Det er de ledende spørgsmål i dette 
bidrag, ${ }^{1}$ som umiddelbart er vigtige, fordi det oftest er en og den samme person, studerende såvel som forsker, som i sit professionelle virke permanent skifter fra den ene til den anden sfære. For individet skal der være sammenhæng og kohærens mellem de to domæner, aktiviteterne skal sammen give 'mening' (Wenger, 1998, s. 51ff).

Et skift til informationshåndterende aktiviteter - eller gangen til biblioteket, om man vil - sker typisk, når en studerende/forsker bliver opmærksom på selve teksten som informationsbærer og 'hopper ud' i en emnebaseret tekstsøgning, som jo, i en vis forstand, ikke hører til de primære akademiske og universitetsbårne lærepraksisser med institutionel højstatus. Enhver bevægelse fra universitetsbaseret forskning og læring til informationshåndtering kaster derfor forskeren/den studerende ud af vedkommendes primære læringskontekst i et begrænset tidsrum. I litteraturen, især den informations- og biblioteksvidenskabelige, karakteriseres denne situation ofte med begreber som 'informationsbehov', 'vidensdiskrepans', 'Anomalous State of Knowledge' - ASK (Belkin) m.m., som antyder en vis problematisk situation bestående af mangel på information, sådan at vedkommende forsøger at afhjælpe denne vidensmæssige 'krise' ved at konsultere flere tekster, som muligvis indeholder den ønskede information, og dermed eliminerer den oplevede mangel (Beghtol, 1986, s. 85; Cooper, 1971, s. 19-26 i forbindelse med relevans; Limberg, Sundin, \& Talja, 2012, s. 111f). Denne diskrepans anses som kernen i de studerendes og forskernes skiften mellem, en 'primær', direkte tekstindholdsrelateret læring og en aktivitet, som retter sig mod tekster som informationsmedier. De følgende overvejelser skal i mere eksplicitte termer påpege de elementer af læringssituationen, som knytter universitetslæring og informationshåndtering sammen og er nødvendige for, at en kohærent og givende læreoplevelse kan opstå for det lærende individ.

Bidraget er struktureret på følgende vis. Efter en diskussion af læringsteoretiske tilgange med særlig fokus på universitetssettings skal der påpeges nogle grundlæggende mekanismer ved, hvordan tekstlæsning og -bearbejdelse på den ene side og teksthåndtering, her især emnesøgning, på den anden side kan spille sammen under én cyklisk læreaktivitet. I denne sammenhæng drøftes, hvordan læringsprocesser relaterer til læringens emne/genstand og på hvilken vis konceptet 'behov for nye tekster' kan incitere en læringsmæssig motiverede bevægelse fra tekstforståelse til teksthåndtering. Til sidst skal der diskuteres nogle af de konsekvenser, som en sammensmeltning af tekstforståelse og teksthåndtering har på det universitetspædagogiske område.

\footnotetext{
${ }^{1}$ Jeg takker mine to bedømmere for godt og konstruktivt input, og en stor tak går også til Adda Salomonsen, cand.mag. og bibliotekar på Hjørring og Hirtshals biblioteker, for en grundig sproglig gennemgang af mit tyskerdansk. Resten af fejl og andet vrøvl går alene på min konto.
} 


\section{Kognitiv-konstruktivistiske tilgange til tekstbaseret læring}

Selvom der er mange teoretiske tilgange og "modeller" for læring, nævnes oftest læringens tre store paradigmer, nemlig behavioristisk og kognitiv læringspsykologi (Grassian \& Kaplowitz, 2009, s. 28-32; Kari \& Savolalinen, 2010, s. 232f; Webb \& Powis, 2004, s. 22-24), og, i særdeleshed, konstruktivismen. På trods af et stort overlap især mellem kognitive og konstruktivistiske antagelser (i det følgende bruges flere gange den kombinerende betegnelse 'kognitiv-konstruktivistisk'), ${ }^{2}$ genspejler i vores kulturkreds sidstnævnte gruppe af teorier med dens læringsinstitutionelle forudsætninger dog i særdeles høj grad et moderne og tidssvarende syn på læring, hvor, ud over det rent kognitive forståelsesarbejde (se nedenfor), også de sociale og kommunikative elementer vægtes højt. Det er derfor måske ikke helt forkert at sige, at disse principper i dag indgår i mange moderne konceptioner af 'formel' læring, som den finder sted på uddannelsesinstitutionerne.

Læring i universitetsdomænet foregår som regel eksplicit og under bevidst tilrettelæggelse og forberedelse af både den studerende og underviseren og er i denne forstand 'formel' (Notari \& Honegger, 2012, s. 23; Pachler \& Daly, 2011, s. 43, 55; Qvortrup, 2006, s. 39). Ved siden af denne eksplicitte læring sker der også implicit læring, 'uformel', automatisk, uden bevidst kontrol. Her er der tale om implicit/tavs viden, der som regel ikke er beskrevet, men som tilegnes i en kommunikativ faglig praksis, herunder skjulte opfattelser og normer, indkulturering og delte holdninger til faget (Dolin, 2013, s. 65f; se også Schreiber, 2011; Wenger, 1998). Undervisning i en universitetssammenhæng, som skal ses som samspil mellem studerende, underviser og det, der skal læres, involverer både implicit og eksplicit viden og læring. Men da brug af tekster i læringssammenhæng på universiteter og højere uddannelser i høj grad er knyttet til eksplicit og formel læring, skal omdrejningspunktet i det følgende være tekster i decideret formelle læringssettings.

Tekstlæsning til læringsformål forbindes endvidere med skellet mellem dybde- og overfladelæring (sml. Littlejohn, 2005; Marton \& Booth, 1997; Wiberg, 2011) og i særdeleshed med en kognitiv-konstruktivistisk læringsforståelse, hvor de studerende bygger deres viden op i vekselvirkning med omgivelserne gennem aktivt arbejde med stoffet og en aktiv konstruktion af deres forståelse af emnet (Cubric, 2012, s. 149; Dolin, 2013, s. 68; Lindquist \& Long, 2011, s. 226). Fokus på et kognitiv-konstruktivistisk læringssyn i højere uddannelser er igen begrundet i den centrale rolle, som tekster og deres kognitive bearbejdning, også i sociale relationer, spiller i læringsaktiviteter i dette domæne.

\footnotetext{
${ }^{2}$ Her skal bemærkes, at den kumulerende sammensætning 'kognitiv-konstruktivistisk', som forudsætter en inhærent semantisk sammenhæng mellem de to bestanddele, er gængs praksis, men at der også eksisterer andre taksonomier. Fx deler Kari \& Savolalinen læringsteorier op i behavioristiske, kognitivistiske og konstruktivistiske (Kari \& Savolalinen, 2010, s. 232).
} 
Grundlæggende for en konstruktivistisk tilgang, og for kognitivt inspirerede læringsteorier i øvrigt, er interaktionen mellem ny information og gammel viden/erfaring (Williams, 2005, s. 62) og den måde, nye erfaringer tilpasses eksisterende skemaer/koncepter (assimilation) eller forårsager ændringer i selve skemaerne (akkomodation) (Petrie \& Oshlag, 1993, s. 583).

\section{Disciplinær læring og informationshåndtering - læringscyklusser}

Læring i universitetsdomænet (eller 'disciplinær læring') betragtes dermed i en konstruktivistisk forståelse ofte, enkelt og basalt, som læsning af tekster, forståelsen af disse, den studerendes intellektuelle forarbejdelse og teksternes genbrug i den studerendes egne tekster, mundtligt eller skriftligt, fx i diskussioner, som studieopgaver, oplæg, publikationer m.m. Denne type af læringsaktivitet forener på en fundamental måde det sociale med det personligt-intellektuelle udviklingsaspekt ved at tilegne sig tekstuelt indhold (og dermed verdenen bag indholdet) og er så grundlæggende, at den nogle gange sættes lig med læring i det hele taget. Disciplinær læring er domænemæssigt placeret på universitetet og andre højere uddannelsesinstitutioner, hvor dens rammer og standarder samt andre disciplinære praksisser for de studerende bliver fastlagt i studieordninger, pensumlister, kompendier og anbefalinger fra universitetslærere (Jensen \& Fibiger, 2004; Schreiber, 2011, s. 99). Selvom denne læring understøttes af forskningsbibliotekerne gennem indkøb og tilgængeliggørelse af materialer, i stigende grad i e-form ( $\mathrm{Li}, 2009$, s. 147, 159-161, 175), forbliver disse aktiviteter universitetets eksklusive domæne, hvori biblioteket, ud over opgaver vedrørende hurtig tilgængeliggørelse, ikke er involveret.

Informationshåndtering (og informationskompetence som mere biblioteksrelateret begreb) kommer derimod i spil, når den lærende forlader sin orientering på tekstforståelse og selve informationen og i stedet forholder sig til selve teksten som bærer af information. Modsætningen mellem tekstforståelse og teksthåndtering er blevet paralleliseret på forskellige måder: Domænemæssigt (universitetet vs. biblioteket), mht. til læringsmodus (kognitiv vs. behavioristisk), under henvisning til den lærendes refleksionsniveau (bevidst vs. ubevidst), i forhold til indhold af læring (disciplinærtfagligt vs. informationsrelateret) og, sidst men ikke mindst, terminologisk ('læring', 'studium', 'forskning', ... vs. 'informationskompetence', 'bibliotekskundskaber', ...).

Et integrativt forhold mellem tekstforstånde og teksthåndterende aktiviteter er blevet behandlet i den biblioteksvidenskabelige litteratur under etiketten 'informed learning' (Bruce \& Hughes, 2010). Her undersøges, hvordan informationsrelaterede aktiviteter forholder sig til læring, både disciplinær og informationskompetenceorienteret. De lærende lærer i denne tilgang om og med information gennem en refleksiv proces, hvor deres opmærksomhed rettes mod selve læringen. Ud fra en fænomenografisk optik (Bruce \& Hughes, 2010, s. A3) skelnes mellem lineære, cykliske og 
simultane tilgange til informationsbrug (Bruce \& Hughes, 2010, s. A4). Den lineære læringserfaring er "først at søge information, derefter at lære fra den". Ved den cykliske modus gennemføres en første lineær sekvens ('søge > lære'), som afsluttes med at identificere behovet for mere information til yderligere læring; derefter følger en ny lineær sekvens 'søge > lære'. I den simultane modus opfattes informationsbrug og læring ikke længere som adskilte aktiviteter. De studerende betragter sig, som Bruce \& Hughes påpeger, selv som lærende, mens de er optaget af at interagere med information (Bruce \& Hughes, 2010, s. A4).

Grundlæggende for alle disse sekventielle modeller af disciplinær læring og informationshåndtering er bevægelsen fra tekst-som-indhold til tekst-som-beholder, som korresponderer til den såkaldte 'conduit-metafor' (Reddy, 1993). Ifølge denne figur er idéer og betydninger (A) 'ting/objekter', sproglige udtryk/ord er (B) 'beholdere' og kommunikation er $(\mathrm{C})$ 'at sende noget $(\mathrm{A})$ i en "beholder" (B) fra $x$ til $\mathrm{y}^{\prime}$. Denne metaforik, som præger vores billede af information, tale og sproglig kommunikation (Lakoff \& Johnson, 1980, s. 10f), indgår i den lærendes forestillinger af tekst og betydning, og karakteriserer det ovenfor beskrevne perspektivskift.

Informationssøgningsprocesser knytter sig på forskellige måder til disciplinær læring. Det kan for den studerende være nødvendigt at finde frem til den første tekst om en given problemstilling, from scratch så at sige, eller vedkommende er ved at uddybe eller supplere et emne, som allerede har været genstand for læring, med andre emnemæssigt beslægtede tekster. Den initiale søgning er ofte som 'emnesøgning' udgangspunkt for den første læsning, som i et andet skridt uddybes/suppleres gennem yderligere søgninger efter 'lignende dokumenter'. Det nye tekstgrundlag kan så føre til en udvidet og mere kompleks læring under inddragelse af flere perspektiver (en grundtanke, som fx udarbejdes hos Marton \& Booth, 1997), som igen kan efterfølges af en ny bearbejdelse af emnets litteraturgrundlag. Formålet med disse aktiviteter er en udvidelse og fordybelse af et givent forskningsspørgsmål eller opgave ved at berige allerede forarbejdede tekster med relaterede tekster, som enten vinkler et emne på en ny måde, eller hjælper til at udvide og uddybe forståelsen ved at inddrage flere aspekter eller mere komplekse forklaringsmodeller.

Informationssøgningsaktiviteter tager i denne cirkel både afsæt fra og peger hen imod en fordybet tekstforståelse (Littlejohn, 2005; Marton \& Booth, 1997), idet al meningsfuld håndtering af information, udvidelse eller vinkling, baserer sig på en forudgående forståelse af udgangstekster. Samtidig leder alle informationssøgningsaktiviteter hen til en ny forståelse, hvor udvidelsen/vinklingen sedimenteres og intellektuelt forarbejdes i en ny runde af forstående læsning. Mens læsning og den diskursive og kognitive bearbejdelse foregår fortrinsvis bevidst og styret (fx i læsegrupper eller formelle undervisningskontekster), så er informationshåndterende processer tit af ubevidst karakter. 


\section{Kognitive og sociale aspekter af læring - igen: cyklisk læring}

Med afsæt i John Dewey (Dewey, 1998) karakteriserer Garrison (2011, s. 9f.) læring som både en konstruktiv og kollaborativ erfaring:

"Thus, an educational experience has a dual purpose. The first is to construct meaning (reconstruction of experience) from a personal perspective. The second is to refine and confirm this understanding collaboratively within a community of learners."(Garrison, 2011, s. 10).

I lyset af de mange informationer, en lærende skal udvælge imellem, tillægges det kollaborative element en fremtrædende rolle, da læringskollektivets funktion er at sikre kvaliteten af det læringsmæssige udbytte op til den kritiske masse, hvor indsatsen i læringsprocessen betaler sig for den lærende, både socialt og personligt (Garrison, 2011, s. 10). En konstruktivistisk læringssituation indeholder dermed komponenter både på det personlige og det sociale plan. I forbindelse med det personlige udbytte skal et læringsindhold kunne tilegnes og forstås med 'rimelige' læringsanstrengelser og samtidig give den lærende tilstrækkelig anledning og motivation til at bygge nyt og bedre indhold $\mathrm{i}$ form af ny viden på den eksisterende viden (disse to komponenter skal afvejes mod hinanden). I den sociale sfære skal der stilles kommunikative mekanismer til rådighed, der giver den lærende mulighed for at afprøve, evaluere og sammenligne sine forståelser og fortolkninger med andres ( $\mathrm{fx}$ faglige diskussionsfora). Konstruktivistisk inspirerede tilgange vidner i høj grad om denne todeling i individuel-personlige og sociale læringselementer, som det påpeges i det følgende.

Det personlige indholdsplan tilhører den kognitive interaktion mellem ny information og gammel viden kombineret med motivationsaspektet (jf. Pink, 2011) og en individuel effektivitetskalkule i forbindelse med 'rimelige læringsanstrengelser'. Autentiske opgaver, håndtering af primærkilder, problemorienteret læring og opdagelseslæring (Grassian \& Kaplowitz, 2009, s. 34f.; Peacock, 2005, s. 166) hører til de pædagogiske faktorer, som gør læringsarbejdet værd for den lærende og motiverer vedkommende til at kaste sig ud i givende læring overhovedet. Hertil kan også regnes alle didaktiske og pædagogisk underbyggede tiltag og læringsrelaterede aktiviteter (Qvortrup, 2006, s. 42), som retter sig mod den mest hensigtsmæssige og effektive læring, herunder fx læringsstile (DaCosta, 2011, s. 39; Peacock, 2005, s. 155, 166; Webb \& Powis, 2004, s. 26-30). Den sociale side af læringen berøres, når fx feedback og synkrone og asynkrone kommunikationsmuligheder i e-læringsplatforme bliver bragt i spil, hvor den lærende reflekterer og interagerer i en virtuel læringskontekst, deler indhold og indgår i online-interaktioner med peers eller underviseren i real time. 
Læring i den universitære tradition foregår på denne baggrund i høj grad symbolsk vha. og gennem tekster, der på det personlige plan skal forstås og intellektuelt bearbejdes. Samtidig finder der i læringsfællesskabet (Cubric, 2012, s. 150; 'community of inquiry', jf. Garrison, 2011) en sideløbende kvalitetssikring af forståelsen sted gennem deltagelse i formelle og uformelle praksisser i det videnskabelige miljø som skrivning af opgaver, deltagelse i undervisning, gruppearbejde, faglige diskussioner, konferencer, publikations- og refereevirksomhed m.m. ${ }^{3}$ I den lærendes individuelle forståelsesproces sættes forandringer i kognitive strukturer i gang gennem læsning af tekster, mens en gruppemæssigt betinget læring indebærer at spejle ens viden i andres, og få input og feedback. Sidstnævnte processer er typisk indlejret i kommunikative handlinger med peers eller underviser, som godkender, validerer og kvalificerer ny viden, enten som bekræftet eller korrigeret/tilpasset forståelse af indhold.

Kognitive og sociale læreprocesser hænger sammen indbyrdes på en cyklisk vis. Kognitive forståelser af en forudgående læsning indgår som 'startstrukturer' eller udgangshypoteser i en efterfølgende fase af social læring. Disse 'oprindelige' forståelser bliver dermed objekt for kommunikative akter i en social udveksling, og forhandles og sammenlignes med andre forståelser. Resultatet er modificerede/forbedrede kognitive strukturer, ny viden. Den første cyklus er dermed afsluttet. I cyklus 2 transfereres den kommunikativt bearbejdede nye viden fra cyklus 1 så igen til den kognitive sfære for en ny omgang kognitiv læring, hvor der i læseakten igen opstår på baggrund af den nye viden - nye, forbedrede kognitive tekstforståelser. Disse, gennem læsning/kognitiv læring modificerede nye forståelser, indgår nu igen i en ny runde social forhandling. Osv.

\section{Emnet og behov for nye tekster}

På baggrund af det sagte kan en konstruktivistisk læringskonstellation endvidere beskrives som en relation mellem et fagligt indhold/emne (eller en problemstilling) som læringsobjekt på den ene side og kognitiv-individuelle og social-kommunikative læreprocesser (omtalt ovenfor) på den anden. Forholdet mellem kognitive og sociale læreprocesser og læringens emne formidler overgangen til informationshåndterende handlinger og beror grundlæggende på den lærendes sammenligningsaktiviteter, som består i løbende at holde sin aktuelle viden sammen med sin fortolkning af emne/problemstilling. På det sociale plan indgår læringens emne, direkte eller indirekte, i de gruppebaserede vidensforhandlinger, idet de lærendes kognitive delresultater

\footnotetext{
${ }^{3}$ Selvom der i de sidste år er blevet arbejdet meget med specifikt at styrke den personlige komponent, $\mathrm{fx}$ gennem universitetspædagogiske tiltag over for det undervisende personale eller indføring af e-læring, fokus på kompetence og en øget orientering på arbejdsmarkedet for akademikere i forhold til området, er intellektuel tekstforståelse, indbygget i en faglig og kritisk dialog, stadigvæk kernen af det, som udgør humanistisk og akademisk professionalisme.
} 
løbende relateres til emnet af alle deltagere i peer-gruppen. Emnet som direkte genstand for læring vil defaultmæssigt være den autoriative instans, som både gruppevalideret viden og individuel viden tilpasses til. ${ }^{4}$

Disse sammenlignings- og kontrolprocesser tillader den lærende at vurdere, hvorvidt vedkommendes aktuelt opnåede viden på de pågældende tidspunkter i læreforløbet korresponderer ${ }^{5}$ med den aktuelle definition af emne/problemstilling. Den lærende relaterer sig dermed ikke kun til de andres viden og emneopfattelser, men sammenligner løbende sin aktuelle viden med sin aktuelle opfattelse af emnet på det pågældende tidspunkt. Hvis nu denne monitorering viser vedvarende uoverensstemmelser og diskrepanser - som også bekræftes i de sociale interaktioner - eller hvis den lærende - eller hele 'community of inquiry' (Garrison, 2011, kap. 3) - har ændret opfattelsen af emnet, så skal der, for at undgå face-threatening konklusioner (fx manglende evner på det kognitive eller sociale område) manipuleres tekstbasis, idet nye tekster inddrages. Vha. disse tekster skal, ifølge den lærendes hypotese, genereres ny viden, som i højere grad korresponderer med emnet henholdsvis problemstillingen. Samtidig skal denne nye viden føre til større accept blandt peers og underviseren/tutoren. Det er, på baggrund af min analyse, udgangssituationen, når det typiske behov for nye tekster opstår.

\section{Universitetspædagogiske perspektiver: når tekstforståelse og teksthåndtering smelter sammen}

Hovedsigtet med denne artikel er at pege på dynamikken i en iterativ universitetspædagogisk læringsmodel, hvor tekstforståelse og -håndtering skifter med hinanden i en, for den lærende, meningsfyldt sekvens. Læring er for en studerende dermed ofte ikke en proces, der begynder, når bogen læses, og slutter, når en litteraturhenvisning skal slås op i bibliotekskataloget; læring kan forbinde disse to processer og subsumerer både biblioteks- og uddannelsesmæssige processer under én kohærent læringsaktivitet. Formålet med universitetslæring er fra dette perspektiv ikke kun forståelse, men i lige så høj grad at tilvejebringe forståelsens forudsætninger i form af en dynamisk tilpasset informationsbasis.

\footnotetext{
${ }^{4}$ Der kan, under optimale omstændigheder, også foretages tilpasninger/modifikationer af selve emnet, både på det individuelle og på det kollaborative plan.

${ }^{5}$ Det at 'korrespondere' kan have flere betydninger, afhængig at individets søgepræferencer, disciplinære traditioner og selve emne-/problemformuleringen. Her kan kvantitative aspekter spille en rolle ("Ved jeg nok?"), kvalitative ("Går min viden dybt nok?"), nyhedsorienteret ("Er min viden ny/aktuel nok eller forældet?") eller andre, fx på innovation rettede, krav ("Er min viden original nok?"). Problemløsningsemner byder i denne sammenhæng på specielle krav, da viden ikke sættes i forhold til et abstrakt emne eller område, men ses i forhold til, hvorvidt viden kan bruges til at løse opgaven.
} 
Fra en universitetspædagogisk vinkel berøres i denne artikel problematikken, hvorvidt læring på universitetet knytter sig til informationshåndterende aktiviteter, som jeg i det foregående har insisteret på gentagne gange, er et afgørende led i den lærendes selvstændige og aktive bearbejdelse af lærestoffet. Hvis disse to typer af læringsaktiviteter, ofte forenklende eksemplificeret som 'tekstlæsning' vs. 'tekstsøgning', kunstigt skilles ad i universitetets institutionelle læringsrammer og undervisningspraksisser, studieordninger og disciplinspecifikke læringstraditioner (Engerer, 2013; Kautto \& Talja, 2007; Limberg et al., 2012; Woolwine, 2010), og betragtes disse aktiviteter endvidere af den studerende selv som adskilte, usammenhængende og inkohærente, vil tekstforståelse og teksthåndtering havne i den uheldige situation, hvor de står i en ressourcemæssig ukonstruktiv konkurrence med hinanden. Læringscyklusserne, som beskrevet i dette bidrag, hæmmes og den studerende vil sandsynligvis ikke opnå de forventede læringsresultater og heller ikke få den fulde læringsoplevelse, hun eller han havde ønsket sig. En af de vigtigste universitetspædagogiske konsekvenser af dette scenario er derfor allerede i undervisningen at tilstræbe ikke at begrænse læring til tekstforstående aktiviteter alene, men at placere den i en frugtbar læringsmæssig sammenhæng med informationshåndterende aktiviteter, som væsentligst består i, at den lærende arbejder sig selvstændigt frem til et individuelt materialegrundlag (tekstsamling), som er egnet til at indgå i efterfølgende forståelsesorienterede læreprocesser.

Dette kan realiseres i undervisningen på forskellige måder, fx ved at give den lærende incitament til selv at skabe og løbende arbejde med sit individuelle informationsgrundlag i forhold til en bestemt problemstilling eller, fra underviserens side, at lade informationshåndterende aktiviteter indgå i undervisningen på lige fod med forståelsesspørgsmål. Også en 'assessment' i form af karaktergivning, eksempelvis for kvaliteten af en litteraturliste ( $\mathrm{i}$ forhold til et emne/en problemstilling), kan i denne sammenhæng diskuteres.

Den her præsenterede analyse af sammenhæng mellem forstående og informationshåndterende læringsaktiviteter viser, at bevægelsen fra forståelse til informationshåndtering kan begrundes i læringsmæssige konstellationer, som danner kontinuitet og sammenhæng for individet. Den lærende kan opfatte sig selv som meningsfuldt handlende i én læreproces, hvor tekster som semantiske objekter for forståelse og strukturel-syntaktiske bærere af information ikke længere er modsætninger, men hvor de to perspektiver motiverer hinanden, uanset om man går til undervisning, diskuterer i en arbejdsgruppe, læser en bog, beskæftiger sig med en fuldtekstbase eller, for den sags skyld, spørger bibliotekaren på fagsalen. Alle sfærer peger på hinanden og giver kun mening sammen. 
Volkmar Engerer har læst sprog $i$ Tyskland og arbejdede bl.a. som videnskabelig medarbejder på Institut for Lingvistik, Technische Universität Berlin, hvor han i 1996 fik sin tyske doktorgrad med en afhandling om sprogindlæring og sprogtab. I 1997 blev han tysk lektor på Germansk Institut, Aarhus Universitet, hvor han forskede bl.a. i fremmedsprogindlæring og underviste danske studerende i tysk sprog og grammatik. I 2000 tiltrådte han en stilling som fagreferent og seniorforsker på Statsbiblioteket $i$ Aarhus, hvor han servicerede sprogfagene på universitetet og forskede i forskellige lingvistiske emner (han initierede bl.a. Statsbibliotekets sproglige forskningskollokvier fra 2000 til 2008). Fra ca. 2008 begyndte han at interessere sig for bibliotekets rolle i forhold til læring og publicerede en række artikler om tværfaglighed, informationskompetence, undervisning, e-læring og formidling af e-ressourcer. I dag er Volkmar Engerer ansat som lektor i Informationsvidenskab og Kulturformidling ved Det Informationsvidenskabelige Akademi, hvor han underviser og forsker inden for læring, kommunikation og sprogets og lingvistiske teoriers rolle i informationsvidenskaben. Man kan lase mere om Volkmar Engerer påhttp://iva.ku.dk/ansatte/?id=451976Evis=medarbejder.

\section{Litteratur}

Beghtol, C. (1986). Bibliographic classification theory and text linguistics: Aboutness analysis, intertextuality and the cognitive act of classifying documents. Journal of Documentation, 42(2), 84-113.

Bruce, C. \& Hughes, H. (2010). Informed learning: A pedagogical construct attending simultaneously to information use and learning. Library $\mathcal{E}$ Information Science Research, 32(4), A2-A8.

Cooper, W. S. (1971). A definition of relevance for information retrieval. Information Storage and Retrieval, 7(1), 19-37.

Cubric, M. (2012). Wiki-supported collaborative learning. In: S. Bocconi, \& G. Trentin (Eds.), Wiki supporting formal and informal learning (s. 145-173). Hauppauge, N.Y.: Nova Science Publishers.

DaCosta, J. W. (2011). Information literacy in the digital environment. In: P. Dale, J. Beard \& M. Holland (Eds.), University libraries and digital learning environments (s. 33-47). Farnham: Ashgate.

Dewey, J. (1998). Experience and education. West Lafayette, Ind.: Kappa Delta Pi.

Dolin, J. (2013). Undervisning for læring. In: L. Rienecker, P. S. Jørgesen, J. Dolin \& G. H. Ingerslev (red.), Universitetspædagogik (s. 65-91). Frederiksberg: Samfundslitteratur.

Engerer, V. (2013). Faglig vs. informationsrelateret læring: integrative elementer i fænomenografiske, sociokulturelle og diskursanalytiske teorier om informationskompetence. Udkommer i: Nordisk Tidsskrift for Informationsvidenskab og Kulturformidling, 2(2), 47-57.

Garrison, D. R. (2011). E-learning in the 21st century: A framework for research and practice (2. ed.). New York: Routledge.

Grassian, E. S. \& Kaplowitz, J. R. (2009). Information literacy instruction: Theory and practice (2. ed.). New York: Neal-Schuman Publishers. 
Jensen, T. W. \& Fibiger, B. (2004). Det annoterede læringsrum - hvordan opbygges et fagligt rum i en digital kontekst? In: M. Georgsen, \& J. Bennedsen (red.), Fleksibel læring og undervisning - erfaringer, konsekvenser og muligheder i ikt (s. 160-173). Aalborg: Aalborg Universitetsforlag.

Kari, J. \& Savolalinen, R. (2010). On the connections between information use and learning process. In: A. Lloyd, \& S. Talja (Eds.), Practising information literacy: Bringing theories of learning, practice and information literacy together (s. 229-249). Wagga Wagga, N.S.W.: Centre for Information Studies, Charles Sturt University.

Kautto, V. \& Talja, S. (2007). Disciplinary socialization: Learning to evaluate the quality of scholarly literature. Advances in Library Administration and Organization, 25, 33-59.

Lakoff, G. \& Johnson, M. (1980). Metaphors we live by. Chicago: The University of Chicago Press.

Li, L. (2009). Emerging technologies for academic libraries in the digital age. Oxford: Chandos.

Limberg, L., Sundin, O. \& Talja, S. (2012). Three theoretical perspectives on information literacy. Human It, 11, 93-130.

Lindquist, T. \& Long, H. (2011). How can educational technology facilitate student engagement with online primary sources? A user needs assessment. Library Hi Tech, 29(2), 224-241.

Littlejohn, A. (2005). Key issues in the design and delivery of technology-enhanced learning. In: P. Levy \& S. Roberts (Eds.), Developing the new learning environment: The changing role of the academic librarian (s. 70-90). London: Facet publishing.

Marton, F. \& Booth, S. (1997). Learning and awareness. New York, London: Routledge.

Notari, M. \& Honegger, B. D. (2012). Wiki: An archetypical tool for collaborative learning in the digital age. In: S. Bocconi \& G. Trentin (Eds.), Wiki supporting formal and informal learning (s. 21-39). Hauppauge, N.Y.: Nova Science Publishers.

Pachler, N. \& Daly, C. (2011). Key issues in e-learning: Research and practice. London: Continuum International Pub. Group.

Peacock, J. (2005). Information literacy education in practice. In: P. Levy \& S. Roberts (Eds.), Developing the new learning environment: The changing role of the academic librarian (s. 153-180). London: Facet publishing.

Petrie, H. G. \& Oshlag, R. S. (1993). Metaphor and learning. In: A. Ortony (Ed.), Metaphor and thought (s. 579-609). Cambridge: Cambridge University Press.

Pink, D. H. (2011). Motivation: Den overraskende sandhed om hvad der motiverer os. København: L\&R Business.

Qvortrup, L. (2006). Knowledge, education and learning: E-learning in the knowledge society. Frederiksberg: Samfundslitteratur. 
Reddy, M. J. (1993). The conduit metaphor: A case of frame conflict in our language about language. In: A. Ortony (Ed.), Metaphor and thought (s. 164-201). Cambridge: Cambridge University Press.

Schreiber, T. (2011). Informationskompetence. Set ud fra to forskellige praksisteorier. Dansk Biblioteksforskning: Tidsskrift for informations- og kulturformidling, 7(2/3), 95-107.

Webb, J. \& Powis, C. (2004). Teaching information skills: Theory and practice. London: Facet publishing.

Wenger, E. (1998). Communities of practice: Learning, meaning and identity. Cambridge: Cambridge University Press.

Wiberg, M. (2011). Forståelse i forskningsbaseret undervisning - især i relation til human- og samfundsvidenskab. Dansk Universitetspædagogisk Tidsskrift, 6(10), 58-63.

Williams, D. (2005). Literacies and learning. In: P. Levy, \& S. Roberts (Eds.), Developing the new learning environment: The changing role of the academic librarian (s. 4969). London: Facet publishing.

Woolwine, D. E. (2010). Generic versus discipline-specific skills. In: A. Lloyd, \& S. Talja (Eds.), Practising information literacy: Bringing theories of learning, practice and information literacy together (s. 169-188). Wagga Wagga, N.S.W.: Centre for Information Studies, Charles Sturt University. 